\title{
Construction site environmental impact in civil engineering education
}

\author{
JOSÉ M. CARDOSO TEIXEIRA* \\ Departamento de Engenharia Civil, Universidade do Minho, Guimarães Portugal
}

(Received 17 May 2003; accepted 29 October 2003)

\begin{abstract}
The environmental impact of construction activity has gained increasing importance in the last few years and become a key subject for civil engineering education. A survey of Portuguese higher education institutions shows that concern with this topic is mostly directed at the impact of large construction projects and especially focused on their operational stage. The impact of construction sites of smaller projects in urban areas tends to merit less attention, despite their importance for citizens and other economic activities taking place in the neighbourhood. Typical negative impacts include noise and dust production, traffic increase, shortage of parking space, visual impacts, etc. Site management is a typical course in most Portuguese undergraduate curricula for civil engineering, the syllabus of which should cater for the above concerns. This paper reports a survey on negative impacts of construction sites in urban areas and presents a set of related subjects that should be considered in civil engineering curricula.
\end{abstract}

Keywords: Construction; Sites; Environment

\section{Introduction}

At present, there are 16 higher education institutions in Portugal offering 5-year undergraduate programmes in civil engineering, with substantial roots in two main engineering schools founded several decades ago: Faculdade de Engenharia da Universidade do Porto (Faculty of Engineering of Porto University) and Instituto Superior Técnico da Universidade Técnica de Lisboa (Technical University of Lisbon). These schools have long established, fairly broad programmes in civil engineering that have subsequently been followed by the newer ones. The degree traditionally covers a variety of areas such as structures, foundations, hydraulics, construction materials, construction technology, roads, town planning, etc. There is now an increasing tendency to offer a 4-year base programme and a final year for specialization, in order to meet EU directions. Typical specialization areas are identical to the ones mentioned above.

Site management is a typical course within the construction technology area. Actually, the broader subject of construction management is not present as an independent area in any

\footnotetext{
*Corresponding author. Email: jct@ civil.uminho.pt
} 
programme of civil engineering in this country. Design-oriented curricula do not leave room for management topics in traditional civil engineering undergraduate profiles. This problem is currently solved at the postgraduate level by a number of MSc programmes (Bezelga and Teixeira 2002).

Typical course names for site management and construction technology from Portuguese civil engineering undergraduate programmes are as listed (Rodrigues and Teixeira 2002) in table 1 .

A significant number of young civil engineers deal directly with construction sites soon after graduation. Some find their first job in the construction industry and become rapidly involved in the management of construction sites; others are employed in consulting companies, performing project management or construction supervision; another group acts as client agents on site, etc. Most of them start their career in site-related activities and continue for several years thereafter. For the sake of simplicity, they are referred to as site engineers in the rest of this paper.

Beyond cost and time planning and control, other management functions such as quality, safety and environmental management now play an important role in the day-to-day work of these professionals. While the former topics are current in most syllabuses of site management and construction technology courses, the latter are seldom found at undergraduate level. However, the environmental management skills of site engineers are becoming a key requirement for both clients and contractor employers. This is due to a number of factors, namely, the environment regulation frame affecting construction sites, the increasing costs of dealing with waste, the pressure of public opinion, the need to proceed to environmental certification for construction companies, etc. Therefore, environmental topics should be further addressed in site management and construction technology courses on undergraduate-level civil engineering programmes.

\section{Impacts of construction sites on the environment}

In the last few years, the impact of the construction industry on the environment has been increasingly recognized. The evaluation of environmental impacts is presently required by law in most countries of the EU, but this applies only to those projects requiring large construction sites. For other projects, namely most of those taking place in urban areas, the evaluation of environmental impact is not compulsory. However, construction sites may cause damage

Table 1. Typical course names.

\begin{tabular}{ll}
\hline Course sets & \multicolumn{1}{c}{ Course names } \\
\hline Site management (SM) & Site management \\
& Company management and site supervision \\
& Construction sites \\
& Site organization and construction management \\
& Construction project management \\
& Construction sites and plant \\
& General construction processes \\
Construction technology (CT) & Construction technology \\
& Steel construction \\
& Maintenance and refurbishment of buildings \\
& Building construction \\
& Building pathology and maintenance \\
& Construction processes \\
& Buildings \\
\hline
\end{tabular}


to the environment, interfering in the daily lives of local residents, who frequently complain about dust, mud, noise, traffic delay, space reduction, materials or waste deposition in public spaces, etc.

There are quite a number of inconveniences because of construction activity, but they have not yet have been adequately detailed and classified. A possible classification according to their relevance in international literature has been suggested (Teixeira and Couto 2000): waste production, mud, dust, soil and water contamination and damage to public drainage systems, destruction of plants, visual impact, noise, traffic increase and parking space shortage, are all damaging to public space. These titles generally refer to sets of inconveniences, grouped together according to their similar pollution effects and/or remedies.

Site engineers will increasingly be required to evaluate the environmental impact of their construction sites. This will certainly become a key element of site plans demanded by construction clients and local authorities and a requirement of company environmental management systems. Some examples of ordinary site impacts and specific knowledge requirements for site engineers are listed later.

\subsection{Waste production}

Like any other economic activity, construction uses natural resources and generates waste. The amount of waste generated by construction and demolition (C\&D) activity is substantial. Surveys conducted in several countries found it as high as $20-30 \%$ of the total waste entering landfills throughout the world (Bossinick and Brouwers 1996). Accordingly, waste-dealing at construction sites has raised substantial international concern.

Generally speaking, C\&D waste may be classified into three types:

- Ordinary construction waste, for example natural stone, sand, mortar, glass, ceramic, etc.

- Not dangerous industrial materials, like plastic, wreck, wood, cardboard, etc.

- Dangerous products or special industrial waste, for example paints, treated wood with heavy metal oxides, asbestos, etc.

Dealing with C\&D waste is a challenging task for young site engineers. Demolition waste is normally produced in large quantities, but it may be highly heterogeneous and hardly reusable (that is, without passing through a recycling process). Ordinary construction waste is otherwise produced in much lower quantities, but it is more difficult to recycle due to high levels of contamination, a large degree of heterogeneity and a considerable amount of chemicals (Bossinick and Brouwers 1996). An effort should be made in order to reduce waste production on site and to increase its recycling value. Additionally, in order to save processing costs, waste should be selected at source prior to the recycling process (Ministére de l'Équipement, du Logement des Transports et du Tourisme 1996). However, waste segregation into the three classes mentioned above involves specific knowledge from site engineers and requires room enough on site to place containers and allow for the operation of trucks, cranes and skilled workers at the selection procedure. Non-selected waste can be disposed of in some public landfills, but a fee must be paid, while eco-centres are free of charge. Most landfills do not accept demolition waste.

\subsection{Contamination of land and water}

Construction makes use of a set of pollutant fluids that may spoil the land and adjacent pavements. Direct evacuation to the sewage system is inconvenient and is actually forbidden in some cases, because it may damage pipes and treatment plants. Paints, solvents, oils and 
washing water from construction sites are some examples of dangerous products. Repair costs of such infrastructures tend to be high for several reasons. Disruption also causes severe inconvenience and must therefore be strongly avoided.

Waste paint, varnish and oil should be carefully collected, thus avoiding their loss in the ground, causing pollution beneath. Workers should be forced to limit the use of excessive shuttering oil, through correct utilization of the products. Alternative oils of vegetable and synthetic base are environmentally better than those of mineral base but significantly more expensive. However, as they are less aggressive for workers, their use should be recommended (Teixeira and Couto 2000).

Washing water from construction sites contains considerable amounts of suspension solids and this is inconvenient for sewage systems and for treatment plants. The maximum allowable quantity for high-density solids (such as minerals) is $200 \mathrm{mg} \mathrm{l}^{-1}$. Most construction materials are compositions of a set of elemental minerals that tend to be dragged out of the site in washing water with higher concentrations than that. Moreover, these effluents are essentially alkaline and may precipitate, which is also a problem. Treatment of washing water of construction sites is thus recommended, aiming at reducing the above inconveniences and further allowing for reuse of treated water. The installation of an equalizing tank is thus desirable for larger sites, while for smaller ones a static decanting tank may possibly be sufficient (Oliveira 2000). In both dynamic and static decanting processes, sludge must be periodically collected and, though it is not a dangerous material, it should be treated in landfills. Site engineers need to become familiar with the essentials of these procedures if they want to enforce an environmental policy on site.

\subsection{Production of dust}

Earth movements, demolition and other similar construction activities often encompass the production of blowing clouds of dust, with pernicious effects on the increasing number of those suffering from respiratory diseases, and unpleasant effects on deposition surfaces. Other examples of dust production operations include several refurbishment activities and cleaning of façades. The installation of dust-preventing facilities should be enforced in these cases, this requiring careful evaluation and selection of adequate preventive measures.

\subsection{Mud on streets}

Earth movements taking place on rainy days often lead to the deposition of mud if tyres of lorries are not cleaned when leaving the construction area. This has several consequences, such as the unpleasant aspect of streets, increased risk of car accidents and higher maintenance costs for public space and private properties. Some simple measures should preferably be implemented on site in order to overcome this problem.

\subsection{Destruction of vegetation}

Construction activities may damage vegetation on site and in its surroundings. Taking into account the importance of trees as natural elements of urban landscape, special care has to be taken in order to ensure their preservation. Nowadays, the preservation of trees is associated with respect for the environment and for the well-being of populations. Diminishing or damaging existing trees may give rise to complaints and to unfavourable public opinion. Moreover, damage to them is often visible some years after the aggression has taken place. Various 
actions may damage and sometimes even lead to the death of trees: soil compaction, substantial increase in the soil level, opening of ditches and trenches, removal of the superficial soil layer, loss or damage to the roots, damaging of the trunk and leaves, etc. Specific preventive measures must therefore be implemented on site in order to avoid such problems. Clearly, this is the kind of topic most young site engineers are not aware of, although it is gaining increasing importance for their current practice.

\subsection{Visual impact}

The visual impact produced by construction site fences is also an important aspect to consider. If in bad condition, it may be viewed as a type of environmental aggression, and some Portuguese city councils already consider it in their local regulations (Regulamento de Resíduos Sólidos do Município de Sintra 1994, Pinto 1997, Normas Municipais de Segurança na Construção da Câmara Municipal de Tomar 1999). Some aesthetic sensitivity of site engineers to this aspect would definitely contribute to an improvement of the appearance of our public places.

\subsection{Noise}

Noise produced by a construction site may affect the right to silence, comfort and health of resident and the visiting population and may influence normal activity of nearby schools, hospitals and other services. The main sources of noise in a construction site are pneumatic hammers, compressors, concrete mixers, operating machinery, several types of horns and acoustic signals, communication among workers, etc. Measurement of noise level produced by construction sites will certainly be enforced in the future, due to the need to conform to regulations and to avoid claims from the neighbourhood. Special site organization measures must therefore be implemented on sites chiefly through the action of site engineers, for example (Teixeira and Couto 2000):

- improve means of communication among workers;

- replace noisy construction operations or minimize their operating time;

- duplicate noisy equipment if there is enough space on site;

- avoid horns unless they are required for safety reasons;

- instruct workers to avoid the use of machinery at full power if possible.

\subsection{Increasing car traffic and reduction of parking spaces}

Traffic of vehicles and machinery from the site or related to the site may introduce a significant increase in local traffic. Parking spaces usually available are often reduced due to the increased demand of workers and suppliers concerned. This calls for obvious site organization measures that need the special concern of site engineers.

\subsection{Damage to public space}

The impact analysis still includes the damaging of public space, as it can be seriously affected, unless proper precautions are taken. The most frequent types of damage are the destruction of pavements, garden spots, gridirons of drains, inspection covers and accumulation of mortar waste and pavements with paint. 


\section{Syllabus of site management courses}

Six main universities offering undergraduate programmes in civil engineering have been surveyed with respect to the content of their site management courses:

- Universidade do Minho (UM).

- Faculdade de Engenharia da Universidade do Porto (FEUP).

- Faculdade de Ciências Técnicas da Universidade de Coimbra (FCTUC).

- Instituto Superior Técnico da Universidade Técnica de Lisboa (IST).

- Universidade do Douro e Trás os Montes (UTAD).

- Universidade da Beira Interior (UBI).

The main undergraduate site management courses taught in these institutions are summarized in table 2.

In view of the contents of table 2, it may be concluded that Portuguese universities follow similar programmes for site management courses at the undergraduate level, basically encompassing the following topics:

- Construction law and construction activity regulations.

- Site layout and organizations.

- Site planning.

- Activity scheduling and resource allocation.

- Estimating and tendering.

- Site plant.

- Health and safety management on site.

\section{Conclusions}

In section 2 , the following set of environmentally relevant topics was found:

- Impact evaluation procedures.

- Site environmental impact plans.

- Waste classification and selection procedures.

- Decanting processes for construction site water disposal.

- Dust-preventing facilities.

- Preservation of trees and other vegetation.

- Aesthetics.

- Noise reduction procedures on site.

The topics of site management courses are otherwise listed in section 3 . The two sets of subjects do not seem to match, thus evidencing lack of site environmental topics in site management courses of Portuguese undergraduate programmes for civil engineering.

A paper of similar content (Teixeira 2002) and an identical conclusion was presented by the author at the Fourth ACEF International Symposium on Environmental Aspects in Civil Engineering Education, held in Porto, Portugal, in September 2002. Other authors have reached identical conclusions for other areas of civil engineering curricula in other countries, but the way to overcome this problem does not seem to be easy.

The introduction of specific courses on environment in ordinary civil engineering programmes as well as alternative learning approaches has been suggested by several authors. The 
Table 2. Topics addressed in site management courses of the main Portuguese universities.

\begin{tabular}{|c|c|}
\hline Institution & Main topics \\
\hline \multirow[t]{5}{*}{ UM } & Site management \\
\hline & Company management and site supervision \\
\hline & Construction sites \\
\hline & Site organization and construction sites \\
\hline & Construction project management \\
\hline \multirow[t]{7}{*}{ FEUP } & Construction company organization \\
\hline & Site planning and control \\
\hline & Site supervision \\
\hline & Site plant \\
\hline & Site layout \\
\hline & Construction law and construction activity regulations \\
\hline & Estimating and tendering for construction projects \\
\hline \multirow[t]{6}{*}{ FCTUC } & Construction terminology and definitions \\
\hline & Construction project measurements \\
\hline & Cost estimation \\
\hline & Site plant \\
\hline & Construction phase preparation \\
\hline & Scheduling construction projects \\
\hline \multirow[t]{8}{*}{ IST } & Fundamentals of construction project undertakings \\
\hline & Construction activity regulations \\
\hline & Site plant \\
\hline & Site layout and organization \\
\hline & Health and safety management on site \\
\hline & Estimating and tendering for construction projects \\
\hline & Quality control \\
\hline & Financial control of constructions projects \\
\hline \multirow[t]{6}{*}{ UTAD } & Continuous production systems versus project production systems \\
\hline & Site layout and organization \\
\hline & Site management practice \\
\hline & Health and safety management on site \\
\hline & Construction project scheduling \\
\hline & $\begin{array}{l}\text { Project management, including basic concepts of human relations, business management, } \\
\text { corporate management and accounting. }\end{array}$ \\
\hline \multirow[t]{10}{*}{ UBI } & The construction industry \\
\hline & Project life cycle from the design preliminaries to tender evaluation \\
\hline & The construction phase, including tender and estimating and financial management \\
\hline & Site layout and organization \\
\hline & Construction project scheduling \\
\hline & Health and safety management on site \\
\hline & Ethics \\
\hline & Construction permits \\
\hline & Site supervision \\
\hline & Real estate evaluation \\
\hline
\end{tabular}

problem is how to get room for new courses in overcrowded programmes, such as Portuguese undergraduate civil engineering, as explained in section 1.

Some undergraduate programmes include courses on environmental impact assessment of civil engineering projects, the contents of which are mostly directed at methods and regulations applicable (Pinho 2002). Obviously, these courses could not possibly handle the implications on the environment caused by all civil engineering activity. It should be within the syllabus of each course that environmental concern should be introduced (Marques and Costa 2002). A special focus on environmental aspects can be addressed in postgraduate studies (Marques 2002), but the contents of courses at the undergraduate level should allow students to reach sufficient professional knowledge. This also applies to site management courses, the contents of which should include topics such as those listed above. 


\title{
References
}

Bezelga, A. and Teixeira, J., Construction management education in Portugal. XXX IAHS World Congress on Housing, Coimbra, Portugal, 9-13 September, 2002.

Bossinick, B. and Brouwers, H., Construction waste: quantification and source evaluation. Journal of Construction Engineering and Management, 1996, 122(1).

Marques, J. C., Postgraduate studies in civil engineering at FEUP and the environmental component. Fourth AECEF International Symposium, Porto, September, 2002.

Marques, J. C. and Costa, A. P., Environmental awareness in the civil engineering degree curriculum at FEUP. Environmental aspects in civil engineering education. Fourth AECEF International Symposium, Porto, September, 2002.

Ministeŕe de l'Eq́uipement, du Logement des Transports et du Tourisme, Les chantiers verts. Qualité environnementale des operations de la construction. Direction de l'Habitat et de la Construction.

Normas Municipais de Segurança na Construção da Câmara Municipal de Tomar, 1999.

Oliveira, A., Tratamento do efluente líiquido de uns estaleiros de construção civil. Internal Report, Mestrado em Engenharia Municipal, Universidade do Minho, Portugal, 2000.

Pinho, P., Environmental impact assessment in civil engineering education: challenges and prospects. Environmental aspects in civil engineering education. Fourth AECEF International Symposium, Porto, September, 2002.

Pinto, A., Estaleiros e o ambiente. Internal Report. Mestrado em Engenharia Municipal, Universidade do Minho, Portugal, 1997.

Regulamento de Resíduos Sólidos do Município de Sintra, 1994.

Rodrigues, M. and Teixeira, J., Health and safety in Portuguese civil engineering curricula. XXX IAHS World Congress on Housing, Coimbra, Portugal, 9-13 September, 2002.

Teixeira, J., Construction site impacts in civil engineering education. Environmental aspects in civil engineering education. Fourth AECEF International Symposium, Porto, September, 2002.

Teixeira, J. and Couto, A., Construction sites and environment in historic Portuguese cities. CIB Symposium on Construction and Environment, São Paulo, Brasil, November, 2000.

\begin{abstract}
About the author
José Manuel Cardoso Teixeira graduated in Civil Engineering and has a Master's degree in Building Construction from the Engineering Faculty of Porto and a $\mathrm{PhD}$ in Construction Management from Loughborough University of Technology. He is an Associate Professor in the Civil Engineering Department of University of Minho, responsible for several courses of undergraduate and Master degree programmes and for research in the area of construction project management.
\end{abstract}

